\title{
Wykorzystanie gier planszowych w nauczaniu przedmiotów przyrodniczych
}

\author{
Board games for natural science education
}

\section{Jacek Francikowski}

Uniwersytet Śląski w Katowicach | jacekfrancikowski@wp.pl ORCID: 0000-0002-9291-7814

\begin{abstract}
Beyond entertainment functions, board games can perform the essential functions of education. There are many games which, in addition to shaping social competences or logical thinking, reasoning and planning, can provide knowledge and expertise to help with natural sciences (physics, chemistry, biology, earth science). In the learning of these subjects there are many problems associated with understanding the content, often new or abstract, and how it is related to students' existing knowledge. It is also important to transfer the knowledge about the operation and the principles governing science. A rich pool of titles with various mechanical and difficulty levels allows using the games as a teaching tool in the classroom, and crucially, outside it.
\end{abstract}

Keywords: board games, education, natural sciences, scientific method 

W nauczaniu przedmiotów przyrodniczych (fizyki, chemii, biologii, geografii) obserwuje się wiele podstawowych kłopotów, z którymi borykają się uczniowie. Wiążą się one z zapamiętywaniem i rozumieniem terminów, a także procesów i zjawisk (często abstrakcyjnych) występujących w naturze. Podobnie jest $\mathrm{z}$ wyciąganiem wniosków oraz przewidywaniem konsekwencji owych zjawisk. Wymienione kłopoty wynikają w dużym stopniu z trudności w wyobrażeniu i łączeniu - przez ucznia - wspomnianych terminów i zjawisk z jego wcześniejszą wiedzą i doświadczeniem z codziennego życia. Często nowo poznawane fenomeny mają nieintuicyjną naturę i niełatwo jest je sobie wyobrazić oraz właściwie zrozumieć, szczególnie gdy dana osoba styka się z nimi po raz pierwszy. W wielu wypadkach nie ma możliwości ich zobaczenia i samodzielnego „zaznania” w klasie. Także kłopoty z motywacją i stopniem zaangażowania na lekcji ograniczają skuteczność nauczania wybranych treści (Lowe, 1988; Żmijowska-Wnęk, 2010; Forsthuber, Motiejūnaitè, de Almeida Coutinho, Baïdak, Horvath, 2011; Krzyżanowska, Wiśniewska, 2009). Wydaje się, że rozwiązaniem niektórych z tych problemów może być użycie gier planszowych (Russell 1999; Bochennek i in., 2007; Alpim i in., 2009; Rose, 2011; Ramani, 2012; Korolczuk, Zambrowska, 2014).

Gry planszowe (analogowe) przeżywają obecnie drugą młodość i ich użytkowanie staje się coraz popularniejszą formą spędzania wolnego czasu. Pomimo rozwoju cyfrowych form rozrywki co roku pojawiają się setki nowych wydań „tradycyjnych”, a na całym świecie, w tym także w Polsce, gracze organizują się w domach, bibliotekach, obiektach kultury czy kawiarniach, by spotkać się przy swoich ulubionych tytułach. Nie dziwi więc, że w tej sytuacji coraz powszechniejsze staje się wykorzystanie nowoczesnych gier planszowych w edukacji (Mayers, 2010; Woods, 2012).

Nowoczesne gry planszowe to zaś już coś więcej niż znane wszystkim Monopoly czy Chińczyk. Oferta i możliwości tych gier są dużo większe i warto przyjrzeć się bliżej ich wartości edukacyjnej. Produkcje, o których tu mowa, stanowią dużo więcej niż proste układy bazujące na zasadzie: „Rzuć kostką - porusz pionek”. Są to oparte na innowacyjnych pomysłach i mechanikach systemy zanurzone w określonej przez autora tematyce (istnieją bardzo złożone symulacje pola walki lub zarządzania państwem). Wymagają od graczy przetwarzania informacji i podejmowania decyzji 
w zakresie zależnym od ich poziomu trudności. Mogą charakteryzować się również inicjowaniem bogatej i różnorodnej interakcji z innymi graczami. Dlatego też pod hasłem „gry planszowe” kryje się ogromna liczba tytułów o rozmaitej mechanice i stopniu komplikacji (daje to szansę dostosowania propozycji do wieku i doświadczenia graczy) i, wbrew nazwie, niekoniecznie muszą one posiadać planszę (dlatego dalej będzie używane samo słowo „gra”). Wykorzystuje się w nich kości, karty, żetony, figurki, kafelki czy inne autorskie elementy i rozwiązania, czasem wyjątkowe dla jednej określonej gry (Mayers, 2010; Woods, 2012). Duża liczba tytułów pozwala na dobranie najodpowiedniejszego pod względem tematyki i realizowanych celów do potrzeb lekcji, poziomu kształcenia i wieku uczniów. Należy zaakcentować, że wiele z tych produkcji nadaje się także (niekiedy wyłącznie) do wykorzystania na wyższych szczeblach edukacji - gimnazjum i liceum. Nie są to więc, jak często mylnie się sądzi, narzędzia dydaktyczne przeznaczone wyłącznie dla jej początkowych etapów - przedszkolnego i podstawowego (Mayers, 2010). Oczywiście, liczba tytułów, które można wówczas zastosować, jest większa, a ograniczenia z nimi związane - mniejsze (np. rozgrywka trwa krócej) (Korolczuk, Zambrowska, 2014).

Wiele $\mathrm{z}$ istniejących propozycji doskonale wpisuje się tematyką lub/i mechaniką w potrzeby kształcenia w zakresie nauk przyrodniczych. Wśród najciekawszych znajdziemy następujące: Pandemia, Origins, Compounded, Myrmes, Wysokie napięcie, $\mathrm{CO}_{2}$, High Frontiers, Ewolucja, FunFactory, TwinTin Bots, The New Science, Robinson Crusoe i wiele innych. Zawierają one zwykle dużą ilość wiedzy merytorycznej, która jest podawana pośrednio, poprzez kontakt z grą. Należą do tej kategorii przestrzenie geograficzne, obiekty kosmiczne, związki chemiczne, gatunki, zjawiska i wielkości fizyczne, postaci i wydarzenia. Co ważne, ich znajomość nie jest niezbędna do tego, by grać i wygrywać. Jednak częste obcowanie z nimi w trakcie rozgrywki wyraźnie ułatwia ich poznawanie i zapamiętywanie. Dodatkowo, ponieważ są one umieszczone w określonym kontekście (czyli fabule/tematyce) i mają zastosowanie, gracze łatwiej je przyswajają.

Mechanika gry i interakcja pomiędzy uczestnikami sprawiają, że abstrakcyjne i trudne do wyobrażenia zjawiska uzyskują nowy kształt. Kluczowym czynnikiem okazuje się także procesowa natura opisywanej 
czynności, co sprawia, że niekonkretne dawniej pojęcia znajdują odbicie w tym, co dzieje się „na planszy”, dzięki czemu łatwiej wytworzyć połączenia z wiedzą zdobytą wcześniej. Ponieważ jest to proces, uczeń ma też określony czas, by w trakcie gry móc opanować wybrane zagadnienia, oraz na to, by popełniać błędy, które są równie istotne dla procesu edukacyjnego. Zyskuje w ten sposób szansę na ich zrozumienie i naprawienie w trakcie trwającej rozgrywki lub w kolejnych. Możliwość popełniania błędów i uczenia się na nich stanowi jeden z najskuteczniejszych sposobów nabywania nowych umiejętności. Aby właściwie zareagować na określony problem, trzeba go najpierw zrozumieć. Gra wymusza więc na graczu zaangażowanie głębokich poziomów przetwarzania informacji, a nie tylko powierzchowny kontakt, jak np. wykład (Jarvis, 2005; Hamm, Robertson, 2010; Waldrop, 2015).

Proces nauki jest wspierany przez cykliczność rozgrywek - kolejne pozwalają utrwalać umiejętności i czynnie je weryfikować. Dodatkowo chęć wygranej i rywalizacji są dobrymi motywatorami do świadomego i pełnego kontaktu z grą. Równocześnie jej użytkownicy mogą uczyć się stosowanych strategii i rozwiązań od siebie nawzajem (Matorin, McNamara, 1996; Gobet i in., 2012; Wiering i in., 2007; Talak-Kiryk, 2010; Bentley, 2011; Linderoth, 2011; Dartigues i in., 2013). Taka struktura doskonale odzwierciedla też złożoność i naturę procesu badawczego. Gracze w trakcie rozgrywki wchodzą $\mathrm{w}$ interakcje $\mathrm{z}$ pewnym modelowym układem opartym na sprecyzowanych zasadach, a wygrana wynika z rozwikłania określonych problemów. Muszą oni te wyzwania rozpoznać, postawić sobie odpowiednie pytania i stworzyć hipotezę, która będzie próbą odpowiedzi i znalezienia rozwiązania (zwycięstwa). Gra szybko zweryfikuje ową hipotezę i jej użyteczność.

Jest to niezwykła sytuacja: mamy w niej równocześnie źródło różnorodnych wyzwań i mechanizm weryfikujący sposoby sprostania im. Powstaje tym samym miniaturowy model świata, gdzie świetne odwzorowanie znajduje procedura postępowania naukowego, typowego również dla naszego codziennego życia, a nie tylko dla działań w laboratorium (Bentley, 2011). Często nie zdajemy sobie sprawy, jakimi zasadami kieruje się nauka i jakie są sposoby dochodzenia do prawdy, a gra stwarza możliwość bliższego przyjrzenia się tym procedurom, przeanalizowania ich i przyswojenia poprzez praktykę. 
Gry są cenne edukacyjnie także ze względu na autentyczność doświadczeń, jakie oferują, aktywizację uczniów, wzbudzanie w nich poczucia sprawczości, kształtowanie ich umiejętności socjalnych i innych miękkich oraz uruchamianie głębszych poziomów przetwarzania informacji. Co ważne, wykazują przy tym wieloaspektowe działanie i dzięki takiej naturze nie rozwijają jednej, wąskiej kompetencji, ale mimowolnie angażują uczniów na najrozmaitsze sposoby (Gobet i in., 2012; Mayers, 2010). Poza kształtowaniem kompetencji formalnych i wiedzy wpływają też na inne obszary kompetencyjne uczniów (Korolczuk, Zambrowska, 2014). Dzięki nim możliwe są ćwiczenia w zakresie:

- działania według ustalonych reguł i przestrzegania zasad;

- rozwijania koncentracji i cierpliwości;

- tworzenia i testowania własnych rozwiązań oraz podejmowania decyzji;

- pracy w grupie i komunikacji - rywalizacji oraz kooperacji;

- przyjmowania odpowiedniej postawy wobec porażki i zwycięstwa oraz odporności na stres;

- logicznego myślenia;

- budowania i testowania strategii;

- odkrywania własnych słabych i mocnych stron, znajdowania roli, w której dana osoba się realizuje;

- kompetencji matematycznych i myślenia algorytmicznego;

- języka angielskiego.

Wiele $\mathrm{z}$ istniejących gier doskonale sprawdzi się w aktywizacji uczniów w ramach przedmiotów przyrodniczych. Aby przybliżyć możliwości nowoczesnych gier planszowych w tym obszarze, przyjrzymy się niektórym z ciekawszych tytułów.

Pandemia to gra kooperacyjna dostępna w polskiej wersji dla 1-4 graczy. Ich zadaniem jest współpracować ze sobą, by sprostać growym wyzwaniom, czyli epidemiom czterech rozprzestrzeniających się chorób (SARS, wąglik, dur brzuszny, cholera). Cel stanowi znalezienie szczepionek na te choroby. Jest to doskonały przykład nowoczesnej gry, w której gracze muszą się komunikować między sobą i podejmują wiele trudnych decyzji determinujących zwycięstwo lub przegraną. Konieczne są wybory między przemieszczeniem się do bardziej zagrożonego obszaru a wyleczeniem chorych na miejscu; podobnie konieczne jest rozważenie pozostawienia, 
użycia lub wymienienia z innym graczem kart-próbek, które się posiada. Uczestnicy w pełni kontrolują swoje działania, a losowość ogranicza się do sposobu rozprzestrzenienia się chorób na mapie. Jest to proces dość nieprzewidywalny, jak w realnych warunkach. W czasie rozgrywki uczestnicy pełnią jedną z pięciu ról (medyk, inżynier, badacz, laborant, koordynator), każda z nich wiąże się zaś z innymi umiejętnościami. Tylko sprawna wymiana informacji miedzy graczami, wykorzystanie owych umiejętności i koordynacja działań pozwolą sprostać wyzwaniu.

Pandemia zawiera dużo informacji z dziedziny biologii, które użytkownik nabywa już przy pierwszej partii, gdyż są one wpisane w mechanikę i tematykę. Gracze zapoznają się z podstawowymi terminami z zakresu epidemiologii i immunologii, jak „szczepionka”, „epidemia”, „odporność”. Mogą obserwować rozprzestrzenianie się chorób oraz pozyskiwać informacje o tym, jak można mu przeciwdziałać. Poza ogromnym ładunkiem emocjonalnym gra zawiera także wiedzę, z którą uczniowie rzadko mają okazję się spotkać w formie innej niż teoretyczna. Dodatkowo gracze bardzo szybko zapamiętują lokalizację miast na mapie, gdyż muszą się przemieszczać między nimi. Na kartach, zbieranych w celu opracowania szczepionki, znajdziemy też informacje o krajach, które przyjdzie im na planszy odwiedzić (ludności, powierzchni itp.).

Compounded to gra w języku angielskim (jednak jego znajomość nie jest konieczna, by z niej korzystać). Każdy z graczy pracuje w laboratorium chemicznym i rywalizuje z innymi graczami o syntezę jak największej liczby związków. Zdobywa w ten sposób punkty i rozwija swoje stanowisko. W Compounded zawarty jest także element komunikacyjny i dyplomatyczny, gdyż niektóre substancje mogą być tworzone przez dwie osoby, a w określonych momentach gracze mają szansę na wymienienie się posiadanymi substancjami. Do budowy związków wykorzystuje się atomy rożnych pierwiastków dostępnych w grze. Gracze szybko zapoznają się ze związkami, jakich mogą użyć, oraz z ich różną dostępnością, podobną do tej istniejącej w przyrodzie (wylosowanie węgla czy wodoru jest bardziej prawdopodobne niż siarki czy wapnia). To ciekawy i angażujący sposób, by przyswoić wiedzę na temat budowy i nazw podstawowych związków chemicznych oraz ich właściwości (np. stan skupienia, łatwopalność). Klimatu grze dodaje tor punktacji, wykonany na bazie tablicy Mendelejewa. Gracze odnotowują zebrane punkty, przesuwając 
się od wodoru ku cięższym pierwiastkom. Compounded jest dobrym przykładem wykorzystania tematyki naukowej i związanych z chemią zjawisk do stworzenia interesującej i wciągającej gry.

High Frontier to rozbudowana gra symulacyjna, w której wcielamy się w eksploratorów Układu Słonecznego. Zadanie graczy polega na budowaniu i wysyłaniu statków kosmicznych w celu zdobycia wody $\mathrm{z}$ innych ciał niebieskich. Jednak nie jest to takie proste. Plansza przedstawia Układ Słoneczny z naniesionymi obiektami oraz potencjalnymi trasami przelotu, które można obrać. High Frontier doskonale pokazuje podstawowe wyzwania, przed jakimi stają kolejne programy i ekspedycje związane z badaniem kosmosu. Gracze muszą zaplanować trasy przelotu z uwzględnieniem orbit, skalkulować zapasy paliwa, uwzględnić masę ładunku przewożonego w drodze powrotnej, skonstruować odpowiednie silniki i systemy kontrolne. Stają przed wieloma różnorodnymi problemami i trudnymi kompromisami. W grze zawarta jest duża ilość wiedzy z zakresu techniki i fizyki. Użytkownicy, zdobywając kosmos i starając się wygrać w wyścigu o najlepsze złoża, obcują z tą wiedzą i poznają jej zastosowanie.

Wsiąść do pociągu to gra o prostych zasadach, wciągająca jednak starszych i młodszych graczy. Ich zadaniem jest budować linie kolejowe pomiędzy największymi miastami na kontynentach świata. Uczestnicy rozgrywki rywalizują ze sobą o pierwszeństwo w tworzeniu linii, starając się jak najsprawniej wypełnić przydzielone im zadania. Gra rozwija umiejętność planowania, a poza tym jest okazją do zapoznania się z lokalizacjami państw i miast. Niewielka liczba rozgrywek wystarczy, by uczestnicy przyswoili te lokalizacje i wzajemne położenie różnych ośrodków, a także kształt kontynentów i krajów.

Poza komercyjnymi grami, które są dostępne na rynku i na których się tu skupiono, istnieją inne możliwości wprowadzenia tego typu produkcji do klasy. Ta druga opcja to tzw. gry print and play (PnP, czyli „drukuj i graj”). Są to propozycje dostępne na licencji creative commons, tj. otwartych zasobów. Mają one zwykle postać plików PDF, które można ściągnąć i wydrukować w dowolnej liczbie, by następnie wykorzystać je w klasie. Jest to względnie prosty i tani sposób, by niewielkim kosztem posiadać w szkole odpowiedni zasób zestawów gier, niezależnie od wielkości grupy. Mamy tu często do czynienia z systemami o prostszej 
mechanice, które można rozegrać w parę minut. Jest to ważne o tyle, że do tej kategorii należy wiele bardzo udanych gier dotyczących tematyki nauk przyrodniczych, które są warte polecenia i przetestowania. Znajdziemy tu takie tytuły jak Antidotum, Go Bugs, Phylo, Swarm, Circulatory System Game, Genarate, Rocket Ships, Ion, Gut Check. Nierzadko nie odbiegają one jakością pomysłu, mechaniką ani wykonaniem od komercyjnych. Trzeba jednak zaznaczyć, że są to zwykle gry w języku angielskim (w przypadku niektórych jest to kwesta jedynie angielskojęzycznej instrukcji). Samo wykonanie takiej gry i przygotowanie jej w wersji polskiej może być ciekawym projektem klasowym (Leemukil i in., 2000; Ramani, 2012).

Istnienie tak dużej liczby produkcji, których tematyka mieści się w obszarze nauk przyrodniczych, wskazuje zarówno na ogromny potencjał zjawisk przyrodniczych jako inspiracji, jak i na zainteresowanie graczy tego typu tematyką. Tutaj szerzej zaprezentowano jedynie cztery tytuły - w celu zarysowania potencjału gier dotyczącego przedstawiania zagadnień często trudnych, gdy są one nauczane w statycznej formie, lub zawierających dużo informacji encyklopedycznych. Obecnie stajemy się coraz bardziej świadomi tego, że uczenie w coraz mniejszym stopniu odbywa się w szkole (Firmhofer, 2011). Dlatego warto spojrzeć na gry o tematyce naukowej jako na dodatkową przestrzeń do kontaktu z tego typu treściami. Jeśli już myślimy o wykorzystaniu gier w szkole, nie może, a wręcz nie powinno ograniczać się ono tylko do 45 minut lekcji. Niekiedy będzie to nawet niewykonalne - ze względu na czas rozgrywki. W tym przypadku można wyobrazić sobie użycie gry jako elementu działań pozalekcyjnych, w których trakcie uczniowie po zapoznaniu się z grą opisują swoje doświadczenia i przemyślenia w kontekście omawianej problematyki. Wyciągają wnioski na temat konsekwencji swoich działań, opisują relacje pomiędzy elementami składowymi gry oraz graczami, odnosząc się do swoich doświadczeń w świecie rzeczywistym. Zapewnienie młodzieży wolnego dostępu do gier ma szansę przynieść największe efekty dydaktyczne. Umożliwienie zaś kontaktu z interesującą ich grą po lekcjach, w bibliotece, w ramach koła naukowego czy w czasie wolnym lub na wycieczce szkolnej - może zaowocować niespodziewanymi rezultatami edukacyjnymi (Mayers, 2010). 


\section{Literatura}

Alpim, V. S. S., Santos, J. B., Silva, J. S. J., Menezes, T. D. C., Amorim, R., Ladeia, B. T. C., Marques, H., Queiroz, L. B., Gandra, M. (2009). Enigma: A Board Game As A Potential Tool For Biochemistry And Microbiology Learning And Integration. Journal of Biochemistry Education, 7(2), 7.

Bentley, N. (2 listopada 2011). Zendo as a tool for teaching the scientific method. Online: <https://nickbentleygames.wordpress.com/2011/11/02/ zendo-as-a-tool-for-teaching-the-scientific-method>.

Bochennek, K., Wittekindt, B., Zimmermann, S. Y., Klingebiel, T. (2007). More than mere games: A review of card and board games for medical education. Medical Teacher, 29(9), 941-948.

Dartigues, J. F., Foubert-Samier, A., Le Goff, M., Viltard, M., Amieva, H., Orgogozo, J. M., Barberger-Gateau, P., Helmer, C. (2013). Playing board games, cognitive decline and dementia: A French population-based cohort study. BMJ Open, 3(8). Online: <https://bmjopen.bmj.com/content/3/8/eoo2998>.

Firmhofer, R. (2011). W szkole czy poza szkołą? Jak uczymy się w epoce postindustrialnej? W: P. Zbieranek (red.), Jak wykorzystać potencjat edukacji pozaszkolnej w Polsce? Gdańsk: Instytut Badań nad Gospodarką Rynkową. Online: <http://biblioteka-krk.ibe.edu.pl/opac_css/ doc_num.php?explnum_id=209>.

Forsthuber, B., Motiejūnaité, A., de Almeida Coutinho, A. S., Baïdak,N., Horvath, A. (2011). Nauczanie przedmiotów ścisłych i przyrodniczych w Europie. Polityka, praktyka i badania naukowe (tłum. J. Czernik). Warszawa: Fundacja Rozwoju Systemu Edukacji. Online: <https://publications.europa.eu/pl/publication-detail/-/publication/bae53054-c26c4c9f-8366-5f95e2187634/language-pl>.

Gobet, F., de Voogt, A., Retschitzki, J. (2012). Moves in Mind. The Psychology of Board Games. Hove: Psychology Press.

Hamm, S., Robertson, I. (2010). Preferences for deep-surface learning: A vocational education case study using a multimedia assessment activity. Australasian Journal of Educational Technology, 26(7), 951-965. Online: <https://ajet.org.au/index.php/AJET/article/view/1027/288>.

Jarvis, M. (2005). Psychology of Effective Learning and Teaching. Cheltenham: Nelson Thornes. 
Korolczuk, R., Zambrowska, M. (2014). Pozwólmy dzieciom grać. O wykorzystaniu gier planszowych $w$ edukacji matematycznej. Warszawa: Instytut Badań Edukacyjnych.

Krzyżanowska, Ł., Wiśnicka, M. (2009). Wykorzystanie eksperymentów i metod aktywizujących w nauczaniu - problemy i wyzwania. Raport z badań. Online: <http://www.kopernik.org.pl/fileadmin/user_ upload/PROJEKTY_SPECJALNE/Interakcja-Integracja/2009/sesja1/ raport_nauczyciele_konferencja_prasowa_14_10_09.pdf $>$.

Leemkuil, H., de Jong, T., Ootes, S. (wrzesień 2000). Review of educational use of games and simulations. Online: <https://ris.utwente.nl/ws/ files/5156063/review_of_educational.pdf $>$.

Linderoth, J. (2011). Exploring Anonymity in Cooperative Board Games. W: Proceedings of DiGRA Conference: Think Design Play. Online: <http:// www.digra.org/wp-content/uploads/digital-library/11312.15167.pdf>.

Lowe, N. K. (1988). Games and toys in the teaching of science and technology. Online: <http://unesdoc.unesco.org/images/0008/000805/080586e.pdf>.

Matorin, A. I., McNamara, J. R. (1996). Using board games in therapy with children. International Journal of Play Therapy, 5(2), 3-16.

Mayer, B., Harris, C. (2010). Libraries Got Games: Aligned Learning through Modern Board Games. Chicago: American Library Association.

Ramani, G. B., Siegler, R. S., Hitti, A. (2012). Taking It to the Classroom: Number Board Games as a Small Group Learning Activity. Journal of Educational Psychology, 104(3), 661-672. Online: <http://www.psy. cmu.edu/ siegler/RamaniSiegHitti-12JEP.pdf>.

Rose, T. M. (2011). A Board Game to Assist Pharmacy Students in Learning Metabolic Pathways. American Journal of Pharmaceutical Education, 75 (9). Online: <https://www.ncbi.nlm.nih.gov/pmc/articles/PMC3230344>.

Russell, J. V. (1999). Using Games To Teach Chemistry. Journal of Chemical Education, 76(4), 487-488.

Waldrop, M. M. (2015). Why we are teaching science wrong, and how to make it right. Nature, 523 (7560), 272-274. Online: <https://www.nature.com/news/ why-we-are-teaching-science-wrong-and-how-to-make-it-right-1.17963>. Wiering, M. A., Patist, J. P., Mannen, H. (2 grudnia 2005). Learning to Play Board Games using Temporal Difference Methods. Online: <http:// citeseerx.ist.psu.edu/viewdoc/download?doi=10.1.1.76.4345\&rep=rep1 \&type $=\mathrm{pdf}>$. 
Woods, S. (2012). Eurogames: The Design, Culture and Play of Modern European Board Games. Jefferson, [North Carolina]: McFarland.

Talak-Kiryk, A. (1 stycznia 2010). Using Games In A Foreign Language Classroom. Online: <http://digitalcollections.sit.edu/cgi/viewcontent. cgi?article $=1488 \&$ context $=$ ipp_collection $>$.

Zagal, J. P., Jochen, R., Hsi, I. (2006). Collaborative games: Lessons learned from board games. Simulation \& Gaming, 37(1), 24-40. Online: <https:// pubweb.eng.utah.edu/ zagal/Papers/Zagal\%2oet\%20al\%2o-\%2oCollaborative\%2OGames\%20-\%20Lessons\%2olearned\%20from\%2oboardgames.pdf>.

Żmijowska-Wnęk, E., Wójcik-Hetman, D., Dziurzyńska-Pyrsz, B., Tarka, Z., Socha, S., Rogala, B., Kocowicz, M., Klimas, K. (2010). Analiza przyczyn problemów w nauczaniu przedmiotów matematyczno-przyrodniczych. Online: <http://innowacyjnyekolog.pl/uploads/files/analiza_przyczyn_ problemow_nauczania.pdf $>$.

Data dostępu do źródeł internetowych wykorzystanych w tekście: 10 grudnia 2016.

dr Jacek Francikowski - fizjolog, adiunkt w Katedrze Fizjologii Zwierząt i Ekotoksykologii, Uniwersytet Śląski w Katowicach

\title{
Wykorzystanie gier planszowych w nauczaniu przedmiotów przyrodniczych
}

\begin{abstract}
Abstrakt: Gry planszowe poza funkcjami rozrywkowymi mogą pełnić istotne funkcje edukacyjne. Istnieje wiele gier zdolnych nie tylko do kształtowania kompetencji społecznych czy logicznego myślenia, wnioskowania i planowania, ale też do przekazywania wiedzy oraz formowania umiejętności z zakresu nauk przyrodniczych (fizyka, chemia, biologia, geografia). W nauczaniu tych przedmiotów pojawia się wiele kłopotów łączących się ze zrozumieniem treści, często nowych lub abstrakcyjnych, oraz z ich powiązaniem z posiadaną już wiedzą. Istotne jest również przekazywanie informacji na temat działania nauki i zasad nią kierujących. Bogactwo tytułów o różnorodnej mechanice i poziomach trudności pozwala stosować gry jako narzędzia dydaktyczne w klasie oraz, co kluczowe, poza nią.
\end{abstract}

Stowa kluczowe: gry planszowe, edukacja, nauki przyrodnicze, metoda naukowa 